\title{
Investigation of Toxic Factors Affecting Cells of Rat Brains Exposed to 3-methylcatechol
}

\author{
George Emílio Sampaio Barreto ${ }^{1,2}$, Elineusa Silva de Oliveira ${ }^{1}$, Flávio Augusto Guerreiro \\ Aragão de Villar ${ }^{1}$, Gleide Souza dos Santos ${ }^{1}$, Rute Maria Ferreira Lima ${ }^{1}$, Silvia Lima \\ Costa $^{1}$, Maria de Fátima Dias Costa ${ }^{1}$, Eryvaldo Sócrates Tabosa Egito ${ }^{3}$ and Ramon Santos \\ El-Bachá ${ }^{1 *}$ \\ ${ }^{1}$ Laboratório de Neuroquímica e Biologia Celular; Departamento de Biofunção; Instituto de Ciências da Saúde; \\ Universidade Federal da Bahia; Campus do Canela; 40110-100; Salvador - Bahia - Brasil. ${ }^{2}$ Programa de Pós- \\ Graduação em Ciências da Saúde; Universidade Federal do Rio Grande do Norte - UFRN; Natal - Rio Grande do \\ Norte - Brasil, ${ }^{3}$ Laboratório de Sistemas Dispersos; Departamento de Farmácia, UFRN, Natal - Rio Grande do \\ Norte-Brasil.
}

\begin{abstract}
The aim of this work was to study the effects of $3 M C$ on the peroxidation of biomolecules in nuclear fractions and nonsynaptic mitochondrial respiration in organelles obtained from rat brains. The cytotoxicity towards rat primary astrocytes in vitro was also tested. 3MC at $1 \mathrm{mM}$ oxidized consuming oxygen at a rate of $1.98 \pm 0.19 \mu \mathrm{M} . \mathrm{min}^{-1}$ and formed reactive quinones. At the same concentration, 3MC induced peroxidation of biomolecules in nuclear fractions obtained from rat brain homogenates and inhibited state $2 \mathrm{FADH}_{2}$-linked respiration in nonsynaptic mitochondria. Furthermore, 3MC oxidized in the culture medium, leading to the formation of quinones. This toluene metabolite was cytotoxic to rat primary astrocytes. The concentration that killed 50\% of cells after $72 \mathrm{~h}$ was 107 $\mu M$. The results of the study indicated a direct relationship between cytotoxicity and 3MC oxidation.
\end{abstract}

Key words: Astrocytes, brain, cytotoxicity, 3-methylcatechol, peroxidation, respiration

\section{INTRODUCTION}

Inert organic solvents such as benzene, toluene, ethylbenzene and xylene (BTEX) have been used by the chemical industry to prepare solid catalysts (Tashino et al., 2005), in polymerization reactions (Shikuma et al., 2005), to dissolve photosensitive compositions (Ishizuka and Kojima, 2005), and to synthesize pesticidal (Mori, 2005) and pharmaceutical compositions (Watanabe et al., 2005), among others. BTEX represent an estimated 35\% of fuel oils. Moreover, benzene and toluene are also gas phase tobacco smoke constituents (Xue et al., 2005). Since these compounds are recognized as hazardous fuels and solvents, methods for determination of aromatic hydrocarbons have been developed for toxicity assessment and confirmation of environmental contamination (Dijke, 2005). Inhalation of BTEX poses a health concern due to high volumes of production and release into the atmosphere.

Biological transformation and volatilization are the major removal mechanisms used in cases of toluene contamination of soils and groundwater. Toluene is a substrate for wild or modified toluene dioxygenases expressed in prokaryotic cells

\footnotetext{
${ }^{*}$ Author for correspondence
} 
leading to the formation of 3- and 4methylcatechols (Arnold et al., 2005). In rats and humans, the hepatic clearance of toluene involves cytochrome P450 2E1 (Béliveau et al., 2005). Apparently the acute neurotoxicity of toluene results from specific receptor-mediated interactions between this solvent and ion channel proteins (Bushnell et al., 2005). Although the toxicity of toluene has been well established, the cytotoxicity of its metabolites has not yet been studied extensively. 3-Methylcatechol (3MC) is a minor metabolite of toluene in the human, but studies have reported that $3 \mathrm{MC}$ is cytotoxic. Inhibition of cell growth and a dose-related decrease in cell viability and cell protein content have been reported in Hela cells exposed to 3MC (Shen, 1998). Furthermore, 3MC induced oxidative DNA damage in rat testis (Nakai et al., 2003).

The effects of $3 \mathrm{MC}$ on the peroxidation of biomolecules in nuclear fractions obtained from rat brains were examined in order to clarify whether this compound could be toxic to the central nervous system. The effects of this molecule on $\mathrm{FADH}_{2}$-linked basal respiration in nonsynaptic mitochondria were also evaluated in order to determine whether $3 \mathrm{MC}$ would be capable of interfering with brain nonsynaptic mitochondrial function. Furthermore, 3MCinduced cytotoxicity to rat primary astrocytes in vitro was investigated using a test that measured the activity of mitochondrial succinate dehydrogenase.

\section{MATERIALS AND METHODS}

\section{Materials}

All reagents used in this study were of analytical grade. 3-Methylcatechol was obtained from Aldrich, São Paulo, São Paulo, and solutions were freshly prepared in $0.01 \mathrm{M} \mathrm{HCl}$ in order to inhibit its autoxidation. $\mathrm{HCl}$ was obtained from Nuclear, Diadema, São Paulo, and phosphate salts from Reagen, Rio de Janeiro, Rio de Janeiro. All the solutions were prepared in type I clinical laboratory reagent water.

\section{Measurement of 3-methylcatechol autoxidation in a cell-free system}

Neutral aqueous solutions of $3 \mathrm{MC}$, like other phenolic compounds, undergo spontaneous oxidative decomposition (Rosenau et al., 2005).
Autoxidation constitutes a multi-step reaction process resulting in reactive oxygen species (ROS) and the formation of quinone derivatives. $3 \mathrm{MC}$ has a maximum light-absorption at $273 \mathrm{~nm}$ in aqueous solution at $\mathrm{pH} 3$. No autoxidation has been observed in acidic conditions. However, samples autoxidize in neutral conditions $(\mathrm{pH} 7.4)$, and a new peak appeared at $320 \mathrm{~nm}$ and increased with time. In the present study, the autoxidation rates of $1 \mathrm{mM} 3 \mathrm{MC}$ were measured at $320 \mathrm{~nm}$ in $1 \mathrm{mM}$ $\mathrm{HCl}, 50 \mathrm{mM}$ phosphate buffer $(\mathrm{pH}$ 7.4) in the absence or in the presence of $17 \mathrm{U}$ superoxide dismutase (SOD; EC 1.15.1.1). 3MC oxidation was also measured by means of a Clark-type oxygen electrode connected to an oxygen monitoring system.

\section{Animals}

One-day-old and adult Wistar rats weighing 250$350 \mathrm{~g}$ were obtained from the Department of Physiology of the Health Sciences Institute, Federal University of Bahia (Salvador, BA, Brazil). All the experimental protocols were conducted according to the regulations established by the Ethical Committee for animal experimentation of the Federal University of Bahia.

\section{Isolation of nuclear fraction}

Nuclear fraction was isolated from the brains of adult rats. To isolate nuclei, three brains were homogenized on ice using a ground-glass pestle in $25 \mathrm{ml}$ of $0.32 \mathrm{M}$ sucrose, $1 \mathrm{mM}$ ethylenediamine tetraacetic acid (EDTA), and $50 \mathrm{mM}$ phosphate buffer ( $\mathrm{pH}$ 7.4). Cells were lysed with 8 up-anddown pestle strokes. Tissue homogenate was centrifuged at $400 \mathrm{~g}$ for 10 minutes at $4{ }^{\circ} \mathrm{C}$ and the supernatant was stocked at $4{ }^{\circ} \mathrm{C}$. The pellet was resuspended in the same buffer and centrifuged again under the same conditions. Supernatants were combined and centrifuged at $1,500 \mathrm{~g}$ for 10 minutes at $4{ }^{\circ} \mathrm{C}$. The nuclei were resuspended in $0.2 \mathrm{M}$ EDTA, 20\% (v/v) glycerol, $0.1 \mathrm{M}$ phosphate buffer ( $\mathrm{pH}$ 7.4). Protein concentrations were determined according to the procedures established by Lowry et al. (Lowry et al., 1951).

\section{Peroxidation assay}

Nuclear fractions (1 $\mathrm{mg}$ protein $/ \mathrm{ml})$ were incubated with $1 \mathrm{mM} 3 \mathrm{MC}$ in $1 \mathrm{mM} \mathrm{HCl}$, and $50 \mathrm{mM}$ phosphate buffer $(\mathrm{pH}$ 7.4) at room temperature for $17 \mathrm{~h}$. Negative controls were 
incubated without $3 \mathrm{MC}$, and positive controls were incubated with $5 \mu \mathrm{M} \quad \mathrm{Fe}_{2} \mathrm{SO}_{4}$ and $0.5 \mathrm{mM}$ ascorbate. The formation of thiobarbituric acid (TBA)-reactive substances (TBARS) was used to assess peroxidation (Slater, 1984; Doblinski et al., 2003). A great variety of oxidized substances form pink TBA complexes, such as malonaldehyde, oxidized sugars and amino acids (Esterbauer and Cheeseman, 1990). All these compounds can be found in nuclear fractions submitted to oxidative stress. After the addition of $2 \mathrm{ml}$ of $0.67 \% \quad(\mathrm{w} / \mathrm{v}) \quad \mathrm{TBA}, 15 \% \quad(\mathrm{w} / \mathrm{v})$ trichloroacetic acid in $0.25 \mathrm{M} \mathrm{HCl}$, samples were boiled in capped tubes for 10 minutes and cooled in fresh water. The reaction mixture was centrifuged at $1,500 \mathrm{~g}$ for 10 minutes. The optical density (OD) was measured at $535 \mathrm{~nm}$ against a blank without TBA.

\section{Nonsynaptic mitochondrial isolation}

Nonsynaptic mitochondria were isolated from the brains of adult rats by differential centrifugation. Brains were homogenized using a ground-glass pestle in $0.2 \mathrm{M}$ mannitol, $75 \mathrm{mM}$ sucrose, $1 \mathrm{mM}$ ethylene glycol-bis[ $\beta$-aminoethyl ether]$\mathrm{N}, \mathrm{N}, \mathrm{N}^{\prime}, \mathrm{N}^{\prime}$-tetraacetic acid (EGTA), $0.05 \%(\mathrm{w} / \mathrm{v})$ bovine serum albumin (BSA), and $1 \mathrm{mM}$ Tris buffer ( $\mathrm{pH}$ 7.4). Homogenates were incubated in the absence (controls) or in the presence of $1 \mathrm{mM}$ 3-methylcatechol for 0,15 or 30 minutes at $37{ }^{\circ} \mathrm{C}$ prior to centrifugation. Two independent experiments were performed. Whole cells, nuclei, cytoskeletons and plasma membranes were removed by centrifugation at $550 \mathrm{~g}$ for 10 minutes at $4{ }^{\circ} \mathrm{C}$, followed by centrifugation of the supernatant at $7,100 \mathrm{~g}$ for 10 minutes at $4{ }^{\circ} \mathrm{C}$. The mitochondrial pellet was resuspended in the same buffer and washed twice at $6,400 \mathrm{~g}$ for 10 minutes at $4{ }^{\circ} \mathrm{C}$ in order to eliminate the excess $3 \mathrm{MC}$, which could have interfered with oxygen uptake measurements. Finally, nonsynaptic mitochondria were resuspended in $1 \mathrm{ml}$ of the same isolation buffer. Protein concentration was measured in the same way as that described for nuclear fractions.

\section{Oxygen uptake}

Oxygen consumption was measured at $37{ }^{\circ} \mathrm{C}$ in a closed chamber containing a Clark type oxygen electrode connected to a monitor. Isolated nonsynaptic mitochondria were suspended in $3 \mathrm{ml}$ of $10 \mathrm{mM} \mathrm{KCl}, 0.2 \mathrm{mM}$ EDTA, $0.25 \mathrm{M}$ mannitol, $0.025 \%(\mathrm{w} / \mathrm{v}) \mathrm{BSA}, 10 \mathrm{mM}$ Tris, and $5 \mathrm{mM}$ phosphate buffer ( $\mathrm{pH} 7.4)$ at a final concentration of $0.4 \mathrm{mg}$ protein $/ \mathrm{ml}$. Succinate was added to a final concentration of $10 \mathrm{mM}$ to induce nonsynaptic mitochondrial basal respiration (state 2). Oxygen uptake in resting conditions was monitored for 12 minutes. Four assays were analyzed for each nonsynaptic mitochondrial fraction.

\section{Cell cultures}

Cultures of isolated cortical astrocytes were prepared as previously described (Booher and Sensenbrenner, 1972; Silva et al., 2007). Briefly, astrocytes were prepared from the neocortex of 1day-old Wistar rat brains, maintained in Dulbecco's modified Eagle's medium (DMEM) supplemented with $10 \%$ fetal calf serum, $2 \mathrm{mM} \mathrm{L-}$ glutamine, penicillin $(100 \mathrm{IU} / \mathrm{ml})$, and streptomycin $(100 \mu \mathrm{g} / \mathrm{ml})$. Cells were grown in a humidified atmosphere of $5 \% \mathrm{CO}_{2}$ and $95 \%$ air at $37{ }^{\circ} \mathrm{C}$, and the culture medium was replaced three times a week. Cultures were used after they had attained confluence. At the time of the experiment, cells were seeded at a density of $8 \times 10^{4}$ cells $/ \mathrm{cm}^{2}$ in a 96-well plate and treated 72 hours later.

\section{Treatment of cells with $3 \mathrm{MC}$}

Sterile dilutions of $3 \mathrm{MC}$ were made in $0.01 \mathrm{M}$ $\mathrm{HCl}$. Logarithm dilutions in the range of 60 to $3,000 \mu \mathrm{M}$ were used to examine the cytotoxic effect of $3 \mathrm{MC}$ on astrocytes and to determine the $\mathrm{EC}_{50}$, which is the concentration of $3 \mathrm{MC}$ that kills $50 \%$ of cells. Eight replicates for each dose were used per 96-well plate. Cultures were exposed to $3 \mathrm{MC}$ for 72 hours.

\section{Cell viability and $3 \mathrm{MC}$ autoxidation}

Cell viability was assessed using the 3-(4,5dimethylthiazol-2-yl)-2,5-diphenyltetrazolium bromide (MTT) assay as described previously (Hansen et al., 1989; Andrade et al., 2005). In brief, this colorimetric assay measures the reduction of MTT by mitochondrial succinate dehydrogenase in intact cells. Because reduction of MTT can only occur in metabolically active cells, the level of activity is a measure of cell viability. The $3 \mathrm{MC}$ oxidation in the medium was monitored spectrophotometrically at $405 \mathrm{~nm}$ based on quinones and melanin-like pigment formation (Lai and Yu, 1997). 


\section{Statistical Analysis}

Results were expressed as the mean \pm SD for each group and Student's $t$-test was used to evaluate statistical differences. Results were expressed as median, $25^{\text {th }}$, and $75^{\text {th }}$ percentiles whenever the normality test failed. In this case, the MannWhitney $U$ test was used to assess statistical differences. Differences were considered to be statistically significant at $\mathrm{P}<0.05$. A nonlinear regression was performed to fit concentrationresponse curves. Statistical comparisons between many groups were performed by analysis of variance (ANOVA) followed by the post hoc Student-Newman-Keuls test. Data were analyzed using the Kruskal-Wallis non-parametric ANOVA with the post hoc Dunnett's method when the normality test failed.

\section{RESULTS}

The oxygen consumption during autoxidation of 1 $\mathrm{mM} 3 \mathrm{MC}$ was estimated quantitatively. The rate of oxygen consumption was $1.98 \pm 0.19 \mu \mathrm{M} \cdot \mathrm{min}^{-1}$ (mean $\pm \mathrm{SD}, \mathrm{n}=15$ ). Fig. $1 \mathrm{~A}$ showed that the addition of $17 \mathrm{U}$ SOD significantly inhibited oxygen consumption by $56 \%$. The formation of quinones during the autoxidation of $3 \mathrm{MC}$ increased the $\mathrm{OD}$ at $320 \mathrm{~nm}$. The rate of increase in OD was $0.0021 \pm 0.0002 \mathrm{~min}^{-1}($ mean $\pm \mathrm{SD}, \mathrm{n}=$ 5 ). The rate of quinone formation decreased significantly by $16 \%$ in the presence of $17 \mathrm{U}$ SOD (Fig. 1B). These data suggested that 3MC spontaneously reacted with oxygen in physiological conditions producing superoxide and reactive quinones. Hence, the possibility has to be considered that exposure of cells to $3 \mathrm{MC}$ could produce oxidative damage.

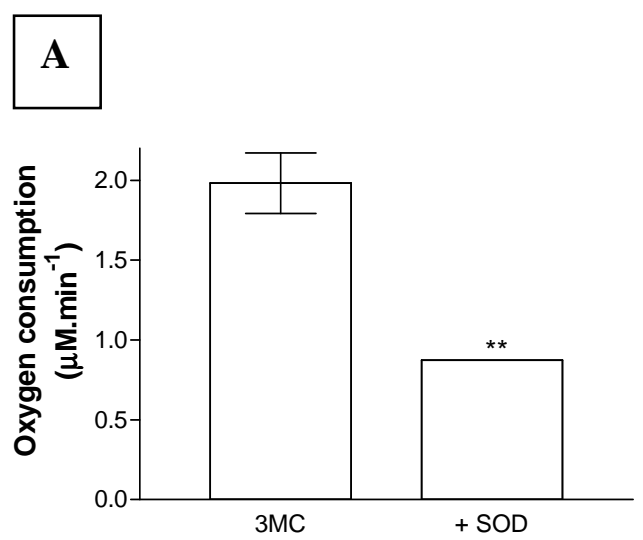

\section{B}

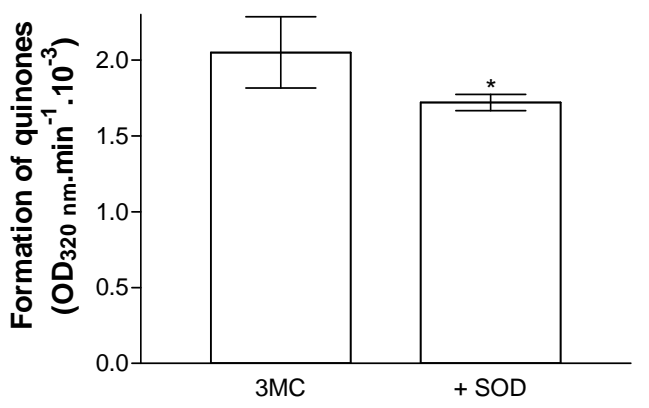

Figure 1 - (A) Oxygen consumption during autoxidation of $1 \mathrm{mM}$ 3-mehylcatechol in $1 \mathrm{mM} \mathrm{HCl}$, $50 \mathrm{mM}$ phosphate buffer $(\mathrm{pH} 7.4)$ at $37^{\circ} \mathrm{C} .3 \mathrm{MC}$ was tested alone (3MC, $\left.\mathrm{n}=15\right)$ or in the presence of $17 \mathrm{U}$ superoxide dismutase $(+\mathrm{SOD}, \mathrm{n}=3)$. Each measurement refers to the mean $\pm \mathrm{SD},(* *), \mathrm{p}<0.0001$. (B) Formation of quinones during autoxidation of 1 $\mathrm{mM} 3 \mathrm{MC}$ in $1 \mathrm{mM} \mathrm{HCl}, 50 \mathrm{mM}$ phosphate buffer ( $\mathrm{pH}$ 7.4). 3MC was tested alone (3MC, $n=5$ ) or in the presence of $17 \mathrm{U}$ superoxide dismutase (+SOD, $n=4)$. Each value represents the mean $\pm \mathrm{SD},(*), \mathrm{p}<0.05$ 
The effects of $3 \mathrm{MC}$ on the peroxidation of biomolecules found in nuclear fractions of rat brain cells were evaluated. The formation of TBARS increased significantly compared to the spontaneous peroxidation in negative controls (58.4\%, $\mathrm{P}<0.001$; Fig. 2A). The peroxidation in positive controls treated with $5 \mu \mathrm{M} \mathrm{Fe} \mathrm{FO}_{4}$ and
$500 \mu \mathrm{M}$ ascorbate for $17 \mathrm{~h}$ increased by $153.2 \%$ compared to negative control values $(\mathrm{P}<0.02$; Fig. 2B). These data showed that a $17 \mathrm{~h}$ exposure of nuclear fractions to $1 \mathrm{mM} 3 \mathrm{MC}$ led to an oxidative stress.
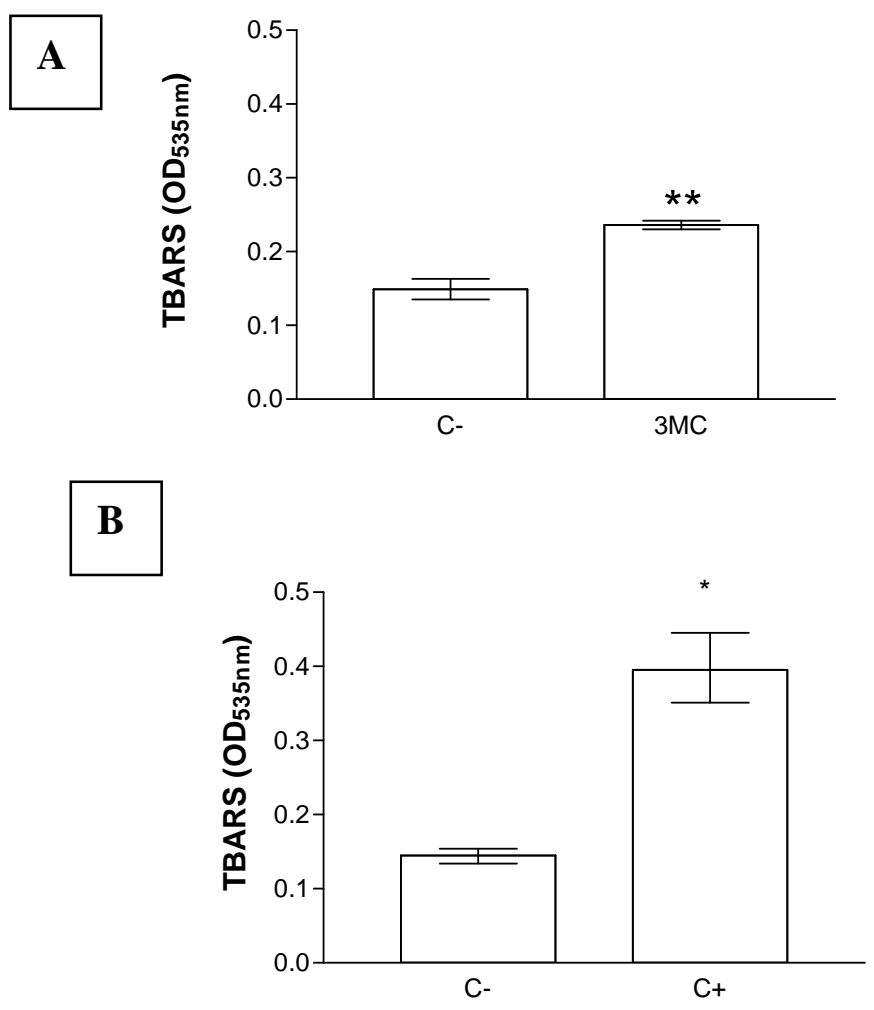

Figure 2 - (A) Mean \pm SD of TBARS levels measured in rat brain nuclear fractions (1 $\mathrm{mg}$ protein/ml) incubated in the absence (C-) or in the presence (3MC) of $1 \mathrm{mM} \mathrm{3-}$ methylcatechol at room temperature for 17 hours. Student's $t$-test was used for comparison, $(* *, p<0.001),(\mathrm{n}=3)$. (B) Median, $25^{\text {th }}$, and $75^{\text {th }}$ percentiles of TBARS levels measured in the nuclear fractions rat brain $(1 \mathrm{mg}$ protein/ml $)$ incubated without (C-) or with $5 \mu \mathrm{M} \mathrm{Fe}_{2} \mathrm{SO}_{4}$ and $0.5 \mathrm{mM}$ ascorbate $(\mathrm{C}+)$ at room temperature for 17 hours. Mann-Whitney U test was used for comparison (*, p $<0.02 ; n=3$ )

Mitochondrial Complex II receives $\mathrm{FADH}_{2}$ directly from succinate dehydrogenase, and is, therefore, mainly dependent on the mitochondrial tricarboxylic acid cycle. In this study, succinate was used to induce nonsynaptic mitochondrial basal respiration (state 2). The rate of oxygen consumption in nonsynaptic mitochondria isolated from rat brain homogenates during state $2 \mathrm{FADH}_{2^{-}}$ linked respiration was $2.5 \pm 0.3 \mathrm{nmol} . \mathrm{min}^{-1} . \mathrm{mg}$ protein $^{-1}$. This rate decreased by $40 \%$ when nonsynaptic mitochondria were isolated after the addition of 3MC (1 $\mathrm{mM})$ to brain homogenates immediately prior to centrifugation (Fig. 3). In another group, nonsynaptic mitochondria were isolated from brain homogenates after incubation at $37{ }^{\circ} \mathrm{C}$ for 15 minutes. The rate of oxygen consumption during state $2 \mathrm{FADH}_{2}$-linked respiration in this group was $3.3 \pm 0.2$ nmol.min ${ }^{-1} \cdot \mathrm{mg}$ protein $^{-1}$. This rate decreased by $51 \%$ when nonsynaptic 
mitochondrial fractions were obtained after the addition of $3 \mathrm{MC}(1 \mathrm{mM})$ to brain homogenates and incubated at $37{ }^{\circ} \mathrm{C}$ for 15 minutes prior to centrifugation. Under the same resting conditions, the mean rate of $\mathrm{FADH}_{2}$-linked oxygen consumption was $2.8 \pm 0.1 \mathrm{nmol} . \mathrm{min}^{-1} . \mathrm{mg}$ protein ${ }^{1}$ when nonsynaptic mitochondrial fractions were obtained after an incubation of brain homogenates with $1 \mathrm{mM} 3 \mathrm{MC}$ at $37^{\circ} \mathrm{C}$ for 30 minutes. Thus, nonsynaptic mitochondrial basal respiration was inhibited by $51 \%$ when $1 \mathrm{mM} 3 \mathrm{MC}$ was added to brain homogenates and incubated at $37{ }^{\circ} \mathrm{C}$ for 30 minutes prior to isolation of nonsynaptic mitochondria. These data suggest that cellular oxidative function may be impaired in the presence of $3 \mathrm{MC}$.

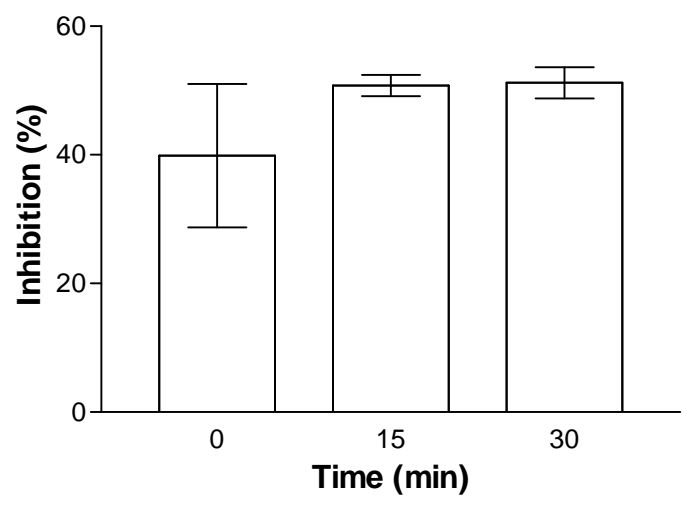

Figure 3 - Relative mean $\pm \mathrm{SD}$ of $3 \mathrm{MC}$-induced inhibition of state $2 \mathrm{FADH}_{2}$-linked respiration in nonsynaptic mitochondria compared to controls. Rat brain homogenates were incubated without (controls) or with $1 \mathrm{mM} 3 \mathrm{MC}$ for 0,15 or 30 minutes at $37{ }^{\circ} \mathrm{C}$ before centrifugation to obtain nonsynaptic mitochondria. Two independent experiments were carried out. Oxygen uptake in resting conditions was monitored for 12 minutes after the addition of $10 \mathrm{mM}$ succinate. Four assays were analyzed for each independent experiment

3MC was probably cytotoxic towards cells from the central nervous system since peroxidation of biomolecules and inhibition of state $2 \mathrm{FADH}_{2-}$ linked nonsynaptic mitochondrial respiration were induced by this compound in vitro. The formation of quinones and cell viability was then assayed in cultures of isolated primary astrocytes to determine the cytotoxicity of 3MC. Cell viability was measured by the use of MTT, which was a substrate for mitochondrial succinate dehydrogenase in intact cells. 3-Methylcatechol oxidation led to a concentration-dependent formation of quinones in the medium of rat astrocyte cultures treated with this molecule for 72 h (Fig. 4). Optical densities measured at $405 \mathrm{~nm}$ in the medium of control cells that were not treated with $3 \mathrm{MC}$ were significantly different from all other groups, $0.012 \pm 0.005$ (mean $\pm \mathrm{SD} ; \mathrm{n}=7$ ). The formation of quinones was well-fitted $\left(\mathrm{R}^{2}=\right.$ $0.981)$ to the equation [1]:

$\mathrm{OD}=0.07+\left\{0.10 /\left[1+10^{(5.34-2.33 \log [3 \mathrm{MC}])}\right]\right\}$ in which OD corresponds to optical density at 405 $\mathrm{nm}$ and $[3 \mathrm{MC}]$ is the $3 \mathrm{MC}$ concentration. When the level of quinones increased with the concentration of catechol, an induction in cell death was detected (Fig. 4). Control cells reduced MTT and the median OD at $560 \mathrm{~nm}$ calculated for this group (median, $0.500 ; 25^{\text {th }}$ percentile, 0.480; $75^{\text {th }}$ percentile, 0,$517 ; \mathrm{n}=7$ ) was considered as $100 \%$ viability. The cell viability of groups treated with concentrations of $3 \mathrm{MC}>100 \mu \mathrm{M}$ differed significantly from that of the controls. The $\mathrm{EC}_{50}$ of $3 \mathrm{MC}$ on rat astrocytes corresponded to $107 \mu \mathrm{M}$ after 72 hours. Equation [2] represents the nonlinear regression calculated from these data $\left(\mathrm{R}^{2}=\right.$ 0.9962):

$\mathrm{V}=3.33+\left\{66.67 /\left[1+10^{(-46.40+22.70 \log [3 \mathrm{MC}]}\right]\right\}[2]$ in which $\mathrm{V}$ is the cell viability normalized to values measured under control conditions and [3MC] corresponds to $3 \mathrm{MC}$ concentration. 


\section{DISCUSSION}

Deliberate or involuntary inhalation of organic solvents causes toxic effects and behavioral changes. Thinner is a neurotoxic mixture containing $60-70 \%$ toluene, which has been shown to induce an increase in lipid peroxidation in the hippocampus, cerebellum and cortex of rats chronically exposed to this solvent (Baydas et al., 2005). Toluene permeabilizes mitochondria (Giulivi et al., 1998) and induced the formation of ROS in rat brain synaptosome fractions (Myhre and Fonnum, 2001), but at concentrations up to $178 \mu \mathrm{g} / \mathrm{ml}$ did not produce cytotoxic effects towards CD3-CD28-stimulated human peripheral blood mononuclear cells (Wichmann et al., 2005). However, $1 \mathrm{mM}$ toluene increased caspase-9 activity in LLC-PK1 immortalized renal proximal tubular epithelial cells derived from the pig, after being treated for 96 hours (Al-Ghamdi et al., 2004). Toluene was also toxic towards primary cultured hippocampus neurons at concentrations above $3 \mathrm{mM}$ after 24 hours (Yan et al., 2004).

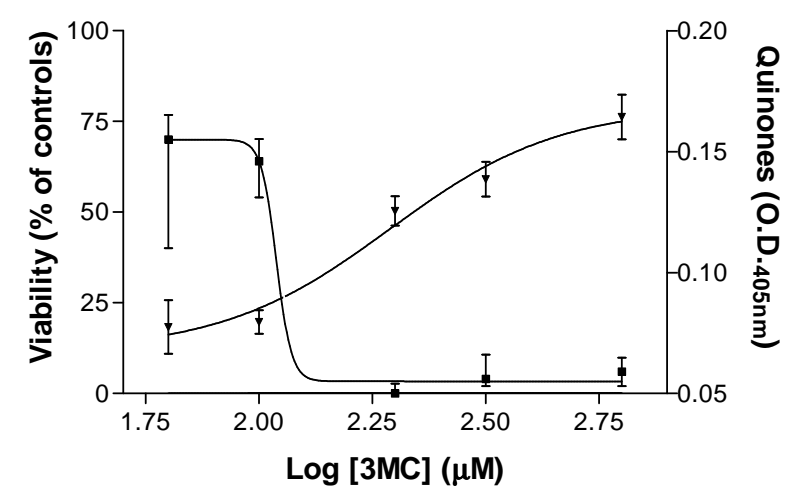

Figure 4 - Concentration-response curves for quinone formation and 3MC-induced cytotoxicity in rat astrocyte cultures after 72 hours. The formation of quinones during the autoxidation of $3 \mathrm{MC}$ was measured by colorimetry at $405 \mathrm{~nm}(\nabla)$. Data on autoxidation are represented by means $\pm \mathrm{SD}, \mathrm{n}=8$. The mean $\mathrm{O}$. D. of the control group was 0.012 . $3 \mathrm{MC}$ autoxidation led to a significant formation of quinones at all concentrations tested $(\mathrm{P}<0.05)$. Statistical significance was analyzed using one-way ANOVA followed by the Student-Newman-Keuls test. 3MC also alters the viability of these cells ( $\boldsymbol{\square})$. Viable cells were quantified colorimetrically using the MTT assay following $72 \mathrm{~h}$ in the presence of $3 \mathrm{MC}$. Data were normalized to the values measured under control conditions (median of OD at $560 \mathrm{~nm}=0.5$ ). 3MC caused a significant reduction in cell viability at concentrations $>100 \mu \mathrm{M}$. Results are shown as medians $\pm 25^{\text {th }}$ and $75^{\text {th }}$ percentiles, $n=8$. Statistical significance was analyzed using the Kruskal-Wallis oneway ANOVA followed by the Dunnett's method

The measurement of oxygen consumption during the autoxidation of $1 \mathrm{mM} 3 \mathrm{MC}$ in $1 \mathrm{mM} \mathrm{HCl}, 50$ $\mathrm{mM}$ phosphate buffer ( $\mathrm{pH}$ 7.4) showed that 1.98 $\mu \mathrm{M}$ oxygen reacted with $3 \mathrm{MC}$ per minute leading to the formation of superoxide, 3-methyl-obenzosemiquinone and 3-methyl-o-benzoquinone, which absorbed light at $320 \mathrm{~nm}$. These results agreed with data obtained during the electrochemical oxidation of 3MC (Fakhari et al., 2005). Scheme 1 shows the reaction of $3 \mathrm{MC}$ with oxygen. 


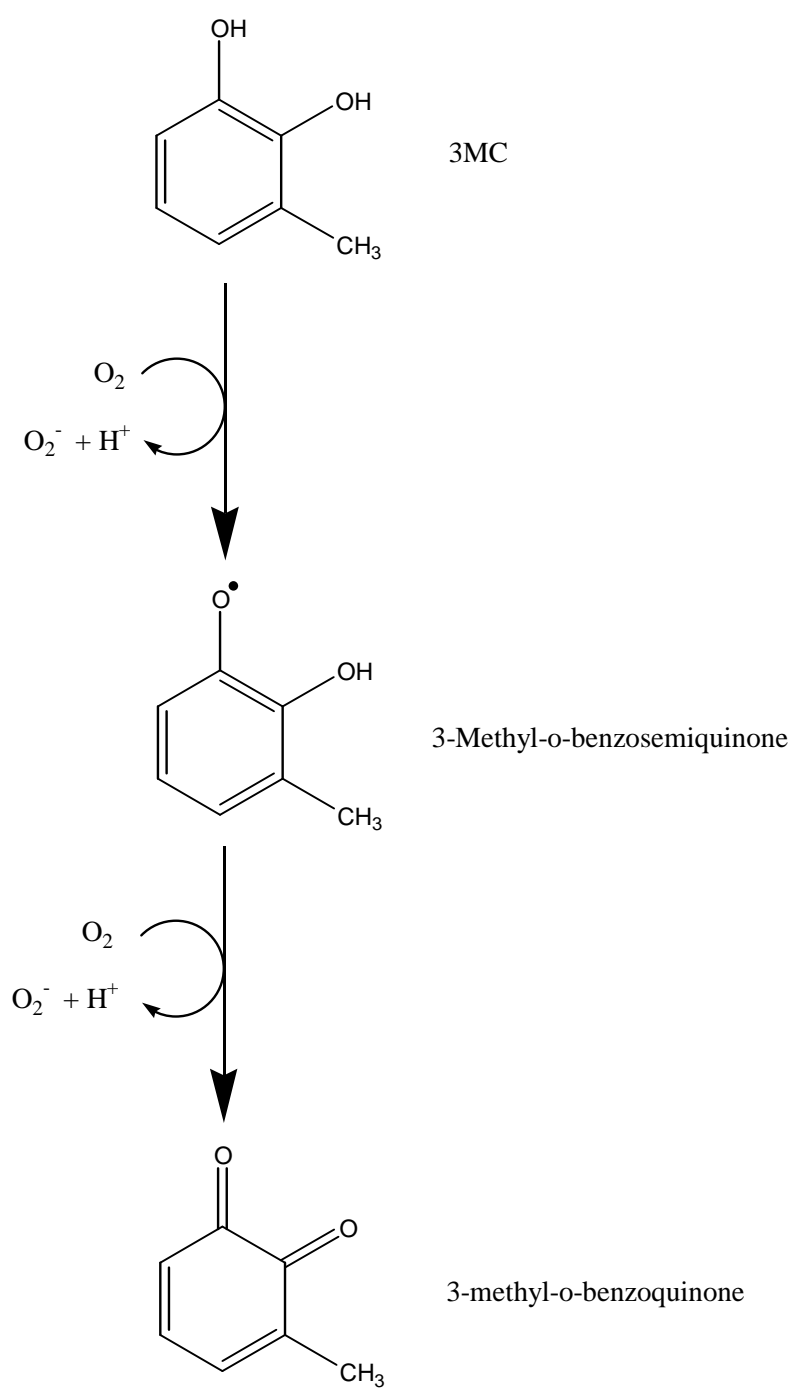

Scheme 1 - Oxidation of 3MC

For the first time it was shown that $3 \mathrm{MC}$ induced the peroxidation of biomolecules in rat brain nuclear fractions. 4-Methylcatechol at concentrations up to $100 \mu \mathrm{M}$ failed to induce lipid peroxidation of rat liver microsomes (Boots et al., 2002). However, the formation of quinones induced a thiol arylation of proteins, which inactivated some enzymes. Several catechols derived from arenes with a heterocyclic group at low concentrations inhibited the lipid peroxidation induced by free radicals in rat brain homogenates (Misawa et al., 2005), but the toxicity of these compounds at higher concentrations was not tested.

The results also showed for the first time that 3MC significantly inhibited state $2 \mathrm{FADH}_{2}$-linked respiration in rat brain nonsynaptic mitochondria. In a previous work, 1,2-dihydroxybenzene (catechol) also inhibited state $2 \mathrm{FADH}_{2}$-linked respiration of rat liver mitochondria (Barreto et al., 2005). These data suggest that catechols may interfere with the respiratory chain. However, further studies need to be carried out to fully clarify the effects of $3 \mathrm{MC}$ on mitochondrial function.

As $3 \mathrm{MC}$ is able to produce superoxide and reactive quinones, induce peroxidation of biomolecules and inhibit $\mathrm{FADH}_{2}$-linked respiration, these processes could account for cytotoxic effects. This study demonstrated that cell viability decreased in cultures of isolated rat cortical astrocytes after treatment with $3 \mathrm{MC}$. The 
decrease in cell viability was accompanied by the production of quinones in the culture medium. The $\mathrm{EC}_{50}$ was $107 \mu \mathrm{M}$ after $72 \mathrm{~h}$. These data correlate with the observed cytotoxicity of 3MC to bluegill sunfish BF-2 fibroblast cells (Shen et al., 2000) indicating that this metabolite of toluene represents a hazardous environmental pollutant. The average amount of $3 \mathrm{MC}$ in one cigarette is 38 $\mu \mathrm{g}$, and $63 \%(24 \mu \mathrm{g})$ is partitioned in the lipid phase of a compartmentalized system (Smith and Hansch, 2000). This means that theoretically this molecule can be stored in lipids that are present in the brain. Despite the fact that $3 \mathrm{MC}$ is present in cigarette smoke condensate, it is listed in the Registry of Toxic Effects of Chemical Substances database under category 6 because there are insufficient data in the scientific literature with respect to its toxicity (Smith and Hansch, 2000). Therefore, this study contributed to update data about $3 \mathrm{MC}$ toxicity in vitro.

Other catechols are also cytotoxic compounds. In a previous study (Pereira et al., 2004), it was demonstrated that catechol was cytotoxic to human glioblastoma cells via the production of superoxide and reactive quinones. Catechol at $230 \mu \mathrm{M}$ killed $50 \%$ of these cells after $72 \mathrm{~h}$. In another work (El-Bachá et al., 2001), the neurotoxicity of apomorphine, a catechol (potent dopamine agonist), was studied. Results showed that the toxicity of this drug was also related to the autoxidation and formation of ROS and quinones. Apomorphine at $200 \mu \mathrm{M}$ killed $50 \%$ of glial C6 cells after 48 h (El-Bachá et al., 2001).

The toxicity of $3 \mathrm{MC}$, one of the major aromatic intermediates of aerobic transformation of toluene in the environment, was evaluated in the organelles and cells of rat brains. This toluene metabolite can elicit peroxidation of biomolecules, inhibition of state $2 \mathrm{FADH}_{2}$-linked respiration in nonsynaptic mitochondria and death of astrocytes. The results of the study indicated a direct relationship between cytotoxicity and 3MC oxidation. Since the cytotoxic effects induced by $3 \mathrm{MC}$ involved an oxidative process, this model could be technologically used for screening the protective and antioxidant activity of biomolecules obtained from natural products.

\section{ACKNOWLEDGEMENTS}

This study was funded by The National Council for Scientific and Technological Development $(\mathrm{CNPq})$, The Fund for Scientific and Technological Development (FUNDECI) and The Foundation for the Support of Research in the State of Bahia (FAPESB). The authors are grateful to the $\mathrm{CNPq}$ for providing a fellowship for E.S.O., and F.A.G.A.V., and to FAPESB for funding a fellowship for G.E.S.B, R.M.F.L., and G. S. S.

\section{RESUMO}

O 3-metilcatecol (3MC) é um metabólito do tolueno. Para esclarecer se o $3 \mathrm{MC}$ seria tóxico para o sistema nervoso central, examinou-se seus efeitos sobre a peroxidação de biomoléculas em frações nucleares e a respiração mitocondrial em organelas obtidas de cérebros de ratos. Também se testou a citotoxicidade para astrócitos primários de ratos. O $3 \mathrm{MC}$ a $1 \mathrm{mM}$ oxida-se consumindo oxigênio a uma taxa de $1,98 \pm 0,19 \mu \mathrm{M} \cdot \mathrm{min}^{-1}$, formando quinonas reativas. Nessa mesma concentração o $3 \mathrm{MC}$ peroxidou biomoléculas nas frações nucleares. Esse composto também inibiu o estado 2 da respiração mitocondrial associada ao $\mathrm{FADH}_{2}$. Além disso, o 3MC também se oxida em meio de cultura levando à formação de quinonas. Esse metabólito do tolueno foi citotóxico para astrócitos de ratos. A concentração que matou $50 \%$ das células após 72 horas foi $107 \mu \mathrm{M}$. Os resultados desse estudo indicam uma relação direta entre a citotoxicidade e a oxidação do 3MC.

\section{REFERENCES}

Al-Ghamdi, S. S.; Raftery, M. J. and Yaqoob, M. M. (2004), Organic solvent-induced proximal tubular cell apoptosis via caspase-9 activation. Environ. Toxicol. Pharmacol., 16, 147-152.

Andrade, L. M.; de Campos, T. P. R.; Leite, M. F. and Góes, A. M. (2005), In vitro response of the numan breast cancer cell line MDAMB-231 and human peripheral blood mononuclear cells exposed to ${ }^{60} \mathrm{Co}$ at single fraction. Braz. Arch. Biol. Technol., 48, 205213.

Arnold, F. H.; Joo, H. and Lin, Z. (2005), Oxygenase enzymes and screening method. California Institute of Technology. USPTO. Pat. N. 6,902,918, USA. 
Barreto, G. E. S.; dos Santos, G. S.; Tabosa, E. S. and El-Bachá, R. S. (2005), Catechol inhibits FADH2linked respiration in rat liver mitochondrial fraction. Acta Cir. Bras., 20 Suppl. 1, 72-77.

Baydas, G.; Osveren, F.; Akdemir, I.; Tuzcu, M. and Yasar, A. (2005), Learning and memory deficits in rats induced by chronic thinner exposure are reversed by melatonin. J. Pineal Res., 39, 50-56.

Béliveau, M.; Lipscomb, J.; Tardif, R. and Krishnan, K. (2005), Quantitative structure-property relationships for interspecies extrapolation of the inhalation pharmacokinetics of organic chemicals. Chem. Res. Toxicol., 18, 475-485.

Booher, J. and Sensenbrenner, M. (1972), Growth and cultivation of dissociated neurons and glial cells from embryonic chick, rat and human brain in flask cultures. Neurobiology, 2, 97-105.

Boots, A. W.; Haenen, G. R. M. M.; Hartog, G. J. M. and Bast, A. (2002), Oxidative damage shifts from lipid peroxidation to thiol arylation by catecholcontaining antioxidants. Biochim. Biophys. Acta, 1583, 279-284.

Bushnell, P. J.; Shafer, T. J.; Bale, A. S.; Boyes, W. K.; Simmons, J. E.; Eklund, C. and Jackson, T. L. (2005), Developing an exposure-dose-response model for the acute neurotoxicity of organic solvents: overview and progress on in vitro models and dosimetry. Environ. Toxicol. Pharmacol., 19, 607-614.

Dijke, A. (2005), Determination of aromatic hydrocarbons in edible oil products. Perkins Coie LLP. USPTO. Pat. N. 0106741A1, United States.

Doblinski, P. M. F.; Ferrarese, M. L. L.; Huber, D. A.; Scapim, C. A.; Braccini, A. L. and Ferrarese-Filho, O. (2003) Braz. Arch. Biol. Technol., 46, 193-198.

El-Bachá, R. S.; Daval, J. L.; Netter, P. and Minn, A. (2001), Is apomorphine neurotoxic? Biogenic Amines, 16, 463-471.

El-Bachá, R. S.; Daval, J.-L.; Koziel, V.; Netter, P. and Minn, A. (2001), Toxic effects of apomorphine on rat cultured neurons and glial C6 cells, and protection with antioxidants. Biochem. Pharmacol., 61, 73-85.

Esterbauer, H. and Cheeseman, K. H. (1990), Determination of aldehydiclipid peroxidation products: malonaldehyde and 4-hydroxynonenal. In Oxygen radicals in biological systems, ed. L. Packer and A. N. Glazer. Academic Press, Inc., San Diego, 186, pp. 407-421.

Fakhari, A. R.; Nematollahi, D. and Moghaddam, A. B. (2005), Electrochemical study of catechols in the presence of 4,6-dihydroxy-2-methylpyrimidine. $J$. Electroanal. Chem., 577, 205-210.

Giulivi, C.; Poderoso, J. J. and Boveris, A. (1998), Production of nitric oxide by mitochondria. J. Biol. Chem., 273, 11038-11043.

Hansen, M. B.; Nielsen, S. E. and Berg, K. (1989), Reexamination, and further development of a precise and rapid dye method for measuring cell growth/cell kill. J. Immunol. Methods, 119, 203-210.
Ishizuka, Y. and Kojima, Y. (2005), Photosensitive composition comprising a phenol resin having a urea bond in the main chain. Kodak Polychrome Graphics, LLC. USPTO. Pat. N. 6,824,947, United States.

Lai, C. T. and Yu, P. H. (1997), Dopamine-, and L- $\beta$ 3,4-dihydroxyphenylalanine hydrochloride (L-Dopa)induced cytotoxicity towards catecholaminergic neuroblastoma SH-SY5Y cells. Biochem. Pharmacol., 53, 363-372.

Lowry, O. H.; Rosenbrough, N. J.; Farr, A. L. and Randan, R. J. (1951), Protein measurement with the folin phenol reagent. J. Biol. Chem., 193, 265-75.

Misawa, N.; Nakamura, R.; Kagiyama, Y.; Ikenaga, H.; Furukawa, K. and Shindo, K. (2005), Synthesis of vicinal diols from various arenes with a heterocyclic, amino or carboxyl group by using recombinant Escherichia coli cells expressing evolved biphenyl dioxygenase and dihydrodiol dehydrogenase genes. Tetrahedron, 61, 195-204.

Mori, T. (2005), Ester compound and its use. Sumitomo Chemical Company, Limited. USPTO. Pat. N. $6,908,945$, USA.

Myhre, O. and Fonnum, F. (2001), The effect of aliphatic, naphthenic, and aromatic hydrocarbons on production of reactive oxygen species and reactive nitrogen species in rat brain synaptosome fraction: the involvement of calcium, nitric oxide synthase, mitochondria, and phospholipase A. Biochem. Pharmacol., 62, 119-128.

Nakai, N.; Murata, M.; Nagahama, M.; Hirase, T.; Tanaka, M.; Fujikawa, T.; Nakao, N.; Nakashima, K. and Kawanishi, S. (2003), Oxidative DNA damage induced by toluene is involved in its male reproductive toxicity. Free Radic. Res., 37, 69-76.

Pereira, M. R. G.; de Oliveira, E. S.; de Villar, F. A. G. A.; Grangeiro, M. S.; Fonseca, J.; Silva, A. R.; Costa, M. F. D.; Costa, S. L. and El-Bachá, R. S. (2004), Cytotoxicity of catechol towards human glioblastoma cells via superoxide and reactive quinones generation. J Bras Patol Med Lab, 40, 281-6.

Rosenau, T.; Potthast, A.; Milacher, W.; Andorjan, I.; Hofinger, A. and Kosma, P. (2005), Discoloration of cellulose solutions in $\mathrm{N}$-methylmorpholine-N-oxide (Lyocell). Part 2: Isolation and identification of chromophores. Cellulose, 12, 197-208.

Shen, Y. (1998), In vitro cytotoxicity of BTEX metabolites in Hela cells. Arch. Environ. Contam. Toxicol., 34, 229-34.

Shen, Y.; West, C. and Hutchins, S. R. (2000), In vitro cytotoxicity of aromatic aerobic biotransformation products in bluegill sunfish BF-2 cells. Ecotoxicol. Environ. Saf., 45, 27-32.

Shikuma, H.; Machida, S.; Ishikawa, M. and Kurokawa, S. (2005), Ethylenic copolymer, composition containing said copolymer, and ethylenic copolymer film. Idemitsu Kosan Co., Ltd. USPTO. Pat. N. 6,844,398, United States. 
Silva, A. M. M.; Silva, A. R.; Pinheiro, A. M.; Freitas, S. R. V. B.; Silva, V. D. A.; Souza, C. S.; Hughes, J. B.; El-Bachá, R. S.; Costa, M. F. D.; Velozo, E. S.; Tardy, M.; Costa, S. L. (2007), Alkaloids from Prosopis juliflora leaves induce glial activation, cytotoxicity and stimulate NO production. Toxicon, 49, 601-614.

Slater, T. F. (1984), Overview of methods used for detecting lipid peroxidation. In Oxygen radicals in biological systems., ed. L. Packer. Academic Press, Inc., Orlando, 105, pp. 283-93.

Smith, C. J. and Hansch, C. (2000), The relative toxicity of compounds in mainstream cigarette smoke condensate. Food Chem. Toxicol., 38, 637-46.

Tashino, K.; Nishiyama, I.; Yoshida, T.; Suzuki, Y.; Ogawa, H. and Sato, M. (2005), Solid catalyst component for olefin polymerization and catalyst. Toho Titanium Co., Ltd. USPTO. Pat. N. 6,878,659, United States.
Watanabe, K. A.; Shi, J. and Otto, M. J. (2005), N4acylcytosine-1,3-dioxolane nucleosides for treatment of viral infections. Pharmasset, Inc. USPTO. Pat. N. 6,908,924, USA.

Wichmann, G.; Mühlenberg, J.; Fischäder, G.; Kulla, C.; Rehwagen, M.; Herbarth, O. and Lehmann, I. (2005), An experimental model for the determination of immunomodulating effects by volatile compounds. Toxicol. in Vitro, 19, 685-693.

Xue, L. L.; Koller, K. B. and Gao, Q. (2005), High efficiency cigarette filters having shaped micro cavity fibers impregnated with adsorbent or absorbent materials. Philip Morris USA Inc. USPTO. Pat. N. $6,907,885$, USA.

Yan, S.; Yin, M.; Wei, Y. and Guo, F. (2004), Study on toxic effects of toluene on primary cultured hippocampus neurons. Wei Sheng Yan Jiu, 33, 18-22.

Received: August 18, 2005; Revised: February 13, 2006; Accepted: April 19, 2007. 